\title{
Assessment of two aerosol optical thickness retrieval algorithms applied to MODIS Aqua and Terra measurements in Europe
}

\author{
P. Glantz and M. Tesche \\ Department of Applied Environmental Science, Stockholm University, Stockholm, Sweden \\ Correspondence to: P. Glantz (paul.glantz@itm.su.se)
}

Received: 8 March 2012 - Published in Atmos. Meas. Tech. Discuss.: 19 March 2012

Revised: 16 June 2012 - Accepted: 18 June 2012 - Published: 19 July 2012

\begin{abstract}
The aim of the present study is to validate AOT (aerosol optical thickness) and Ångström exponent $(\alpha)$, obtained from MODIS (MODerate resolution Imaging Spectroradiometer) Aqua and Terra calibrated level 1 data $(1 \mathrm{~km}$ horizontal resolution at ground) with the SAER (Satellite AErosol Retrieval) algorithm and with MODIS Collection 5 (c005) standard product retrievals $(10 \mathrm{~km}$ horizontal resolution), against AERONET (AErosol RObotic NETwork) sun photometer observations over land surfaces in Europe. An inter-comparison of AOT at $0.469 \mathrm{~nm}$ obtained with the two algorithms has also been performed. The time periods investigated were chosen to enable a validation of the findings of the two algorithms for a maximal possible variation in sun elevation. The satellite retrievals were also performed with a significant variation in the satellite-viewing geometry, since Aqua and Terra passed the investigation area twice a day for several of the cases analyzed. The validation with AERONET shows that the AOT at 0.469 and $0.555 \mathrm{~nm}$ obtained with MODIS c005 is within the expected uncertainty of one standard deviation of the MODIS c005 retrievals $(\triangle \mathrm{AOT}= \pm 0.05 \pm 0.15 \cdot \mathrm{AOT})$. The AOT at $0.443 \mathrm{~nm}$ retrieved with SAER, but with a much finer spatial resolution, also agreed reasonably well with AERONET measurements. The majority of the SAER AOT values are within the MODIS c005 expected uncertainty range, although somewhat larger average absolute deviation occurs compared to the results obtained with the MODIS c005 algorithm. The discrepancy between AOT from SAER and AERONET is, however, substantially larger for the wavelength $488 \mathrm{~nm}$. This means that the values are, to a larger extent, outside of the expected MODIS uncertainty range. In addition, both satellite retrieval algorithms are unable to estimate $\alpha$ accurately, although the MODIS c005 algorithm performs better. Based on the
\end{abstract}

inter-comparison of the SAER and MODIS c005 algorithms, it was found that SAER on the whole is able to obtain results within the expected uncertainty range of MODIS Aqua and Terra observations.

\section{Introduction}

Beside an increase in greenhouse gases, human activities have lead to a perturbation of the atmospheric content of aerosol particles (IPCC, 2007). Aerosols exhibit a high spatial and temporal variability in the atmosphere. Therefore, studies of the effects of aerosols on climate and measures for environmental control require an accurate identification of aerosol sources, their strength, and the released aerosol type. Such information can be retrieved from space-borne observations, and several contemporary satellite-borne radiometers have produced data for aerosol investigations during the last decade. Aerosol optical thickness (AOT) is a useful parameter to estimate the impact of aerosols on air quality and climate, since it can be applied in radiative transfer calculations and for evaluation of the treatment of aerosols in regional and climate models. However, satellite retrieval is no straightforward task, since the radiance at the top-of-atmosphere (TOA) as detected by the nadir viewing sensors is, beside aerosols, also affected by gases and surface reflection. In addition, a relationship between the radiance at the TOA and AOT has to be valid for all possible illumination and viewing geometries. Beside the development of retrieval algorithms, high priority should therefore also be given to the validation of aerosol optical properties from satellite observations against ground-based data. Furthermore, results of remote sensing observations from different space-borne platforms as well as

Published by Copernicus Publications on behalf of the European Geosciences Union. 
by different sensors mounted on the same satellite need to be evaluated. In a recent paper, Mishchenko et al. (2010) have evaluated AOT, obtained by the Multi-angle Imaging SpectroRadiometer (MISR, Kahn et al., 2005) and MODerate resolution Imaging Spectroradiometer (MODIS, Remer et al., 2008), against measurements by ground-based sun photometers in the frame of the AErosol RObotic NETwork (AERONET, Holben et al., 1998). MISR and MODIS are both mounted onboard the NASA Earth Observing System's Terra spacecraft and scan the Earth's surface in a polar orbit. The agreement of ground- and satellite-based AOT presented by Mishchenko et al. (2010) is far less favorable than what has been obtained in previous studies (e.g. Kahn et al., 2005, 2009; Liu et al., 2004; Remer et al., 2008). Kahn et al. (2011) suggest that the reasons for these discrepancies can be explained to a large extent by the analysis approach that (in comparison to the earlier studies) differs in (1) the treatment of outliers, (2) the application of absolute versus relative criteria for testing agreement, and (3) the ways in which seasonally varying spatial distributions of coincident retrievals are taken into account. Kahn et al. (2011) furthermore criticize that Mishchenko et al. (2010) do not distinguish between observational sampling differences and retrieval algorithm error.

As another point, the evaluation of satellite aerosol retrievals should also account for the diversity of algorithms that are currently in use. Kokhanovsky et al. (2010) compare several major aerosol retrieval algorithms by using a synthetic data set of TOA radiation for a model atmosphere and under the assumption of a black surface. In this way, the assumptions made in the different aerosol models that are incorporated in the various algorithms could be investigated. One important conclusion of this study is that accurate aerosol models are needed in combination with better methods of how to choose the right one for the actual situation. They also concluded that improved sensors are needed to reduce systematic errors and recommend multiangle spectropolarimetric measurements.

The aim of the present study is to validate AOT and the Ångström exponent $(\alpha)$, obtained from MODIS observations with a modified version of the Bremen AErosol Retrieval (BAER) algorithm (von Hoyningen-Huene et al., 2003, 2011), hereafter referred to as Satellite AErosol Retrieval (SAER), and MODIS collection 5 (c005) standard aerosol product (Remer et al., 2008) against AERONET sun photometer observations over land surfaces in Europe. Findings of the SAER retrievals are furthermore compared to MODIS c005 for all Terra and Aqua scenes included in this study. In previous studies BAER has been applied to satellite data obtained by the MEdium Resolution Imaging Sensor (MERIS), Sea-viewing Wide Field Sensor (SeaWiFS) and MODIS (e.g. von Hoyningen-Huene et al., 2006, 2011; Glantz et al., 2009a,b). Hence, this algorithm has a good development potential for urban air-quality studies ( $\mathrm{Tr}-$ effeisen et al., 2007; Glantz et al., 2009a; Rohen et al.,
2011). For example, by using the full-resolution MERIS data $(\sim 300 \mathrm{~m})$, it seems that the satellite retrievals can resolve the increased aerosol concentrations along the main highways close to the city of Stockholm (Glantz et al., 2009a). However, von Hoyningen-Huene et al. (2006) and Glantz et al. (2009a) found that AOT retrieved with BAER from MODIS Aqua and MERIS data was lower than AERONET observations in case of high aerosol loading and approximately a factor of 2 higher for low aerosol loading. From an inter-comparison between BAER MODIS Aqua and MERIS, Glantz et al. (2009a) also suggest a bias in AOT for situations with differences in the elevation of the sun. This was caused by a $\sim 1$-h time difference in the overpasses of the satellites. However, differences in the viewing angle of the two sensors could as well contribute to the observed discrepancy in AOT. By introducing a surface bi-directional reflectance distribution function (BRDF) in combination with an air mass-corrected reflectance, von Hoyningen-Huene et al. (2011) found a better agreement in AOT between MERIS and AERONET. Note that MERIS scenes are associated with a relatively narrow swath width. MODIS scenes are on the other hand substantially broader, which means that the present SAER algorithm has here been validated for situations with a larger variation in the satellite viewing geometry compared to aerosol retrievals based on MERIS data. The time periods investigated in this study have been chosen to cover a maximal possible variation in sun elevations in the validation of the two aerosol retrieval algorithms.

\section{Aerosol retrievals, data sources and analysis methods}

\subsection{Satellite nadir viewing}

The MODIS observations considered in this study were thus performed at various sun elevations. MODIS is a nadirviewing instrument on a sun-synchronous near-polar orbit. The radiometer scans the Earth's surface $90^{\circ}$ left and right to the ground-track and produces scenes with a swath width of $2330 \mathrm{~km}$ at ground level, which can be compared to $1150 \mathrm{~km}$ for the MERIS scenes. Thus, aerosol retrievals based on MODIS data are, besides elevation of the sun, highly dependent on the viewing angle of the sensor, which varies between $0^{\circ}$ and $\sim 65^{\circ}\left(0^{\circ}\right.$ to $\sim 40^{\circ}$ for MERIS $)$. For some of the cases investigated here, two daily overpasses over the AERONET stations occurred due to the broad scenes produced by the MODIS sensor. The local equatorial crossing times are approximately 10:30 a.m. (descending node) and 01:30 p.m. LT (local time) (ascending node) for Terra and Aqua, respectively. Hence, the sun-zenith and satellite-viewing geometry always differ between the overpasses of the two platforms. 


\subsubsection{SAER algorithm}

The SAER algorithm has been used to retrieve AOT from calibrated level 1 TOA radiances measured with the nadirviewing sensor MODIS over land surfaces. MODIS measures upwelling or TOA radiance $\left(I_{\mathrm{TOA}}\right)$ at visible and nearinfrared wavelengths. Normalizing of $I_{\mathrm{TOA}}$ in reference to the solar extraterrestrial irradiance $\left(E_{0}\right)$ for each wavelength $\lambda$ results in the spectral TOA-reflectance $\rho_{\mathrm{TOA}}$ :

$\rho_{\mathrm{TOA}}\left(\lambda, \theta_{0}, \theta_{\mathrm{s}}, \Phi\right)=\frac{\pi \cdot I_{\mathrm{TOA}}}{E_{0} \cdot \cos \left(\theta_{0}\right)}$

where $\theta_{0}$ and $\theta_{\mathrm{s}}$ are the solar zenith and satellite viewing angles, respectively, and $\Phi$ is the azimuth angle.

Retrieving AOT from measurements of $\rho_{\mathrm{TOA}}$ requires a solution of the radiative transfer equation for the aerosol reflectance $\rho_{\text {Aer }}$ (Kaufman et al., 1997; von Hoyningen-Huene et al., 2003, 2006):

$\rho_{\text {Aer }}\left(\lambda, \theta_{0}, \theta_{\mathrm{s}}, \Phi\right)=\rho_{\text {TOA }}\left(\lambda, \theta_{0}, \theta_{\mathrm{s}}, \Phi\right)-\rho_{\text {Ray }}\left(\lambda, \theta_{0}, \theta_{\mathrm{s}}, \Phi\right)$

$-\frac{T_{\text {Ray }}\left(\lambda, M\left(\theta_{0}\right)\right) \cdot T_{\text {Ray }}\left(\lambda, M\left(\theta_{\mathrm{s}}\right)\right) \cdot T_{\text {Aer }}\left(\lambda, M\left(\theta_{0}\right)\right) \cdot T_{\text {Aer }}\left(\lambda, M\left(\theta_{\mathrm{s}}\right)\right) \cdot A_{\text {Surf }}\left(\lambda, \theta_{0}, \theta_{\mathrm{s}}, \Phi\right)}{1-A_{\text {Surf }}\left(\lambda, \theta_{0}, \theta_{\mathrm{s}}, \Phi\right) \cdot \rho_{\mathrm{Hem}}\left(\lambda, \theta_{0}\right)}(2)$

where $\rho_{\text {Ray }}$ is the path reflectance of the Rayleigh scattering. $T_{\text {Ray }}$ and $T_{\text {Aer }}$ represent the total (direct and diffuse) atmospheric transmission for the illumination and viewing geometry with respect to gases and aerosols, respectively. $M$ is the air mass factor and $\rho_{\mathrm{Hem}}$ is the hemispheric reflectance. $T_{\text {Ray }}$ and $T_{\text {Aer }}$ as well as $\rho_{\mathrm{Hem}}$ are determined by parameterizations as derived from radiative transfer calculations (von Hoyningne-Huene et al., 2006). For the determination of AOT, a surface reflectance $A_{\text {Surf }}$ is estimated based on a mixing model of green vegetation $\left(\rho_{\mathrm{Veg}}\right)$ and bare soil $\left(\rho_{\text {Soil }}\right)$ spectra:

$A_{\text {Surf }}(\lambda)=F \cdot\left[C_{\mathrm{Veg}} \cdot \rho_{\mathrm{Veg}}(\lambda)+\left(1-C_{\mathrm{Veg}}\right) \cdot \rho_{\mathrm{Soil}}\right]$

with

$C_{\mathrm{Veg}}=\mathrm{NDVI}=\frac{\rho_{\mathrm{TOA}}(858 \mathrm{~nm})-\rho_{\mathrm{TOA}}(645 \mathrm{~nm})}{\rho_{\mathrm{TOA}}(858 \mathrm{~nm})+\rho_{\mathrm{TOA}}(645 \mathrm{~nm})}$

where NDVI is used as a proxy for the vegetation fraction and the scaling factor $\mathrm{F}$ for the level of the surface reflectance determinate at $645 \mathrm{~nm}$ :

$F=\frac{\rho_{\mathrm{TOA}}(645)-\rho_{\mathrm{Ray}}(645)}{C_{\mathrm{Veg}} \cdot \rho_{\mathrm{Veg}}(645)+\left(1-C_{\mathrm{Veg}}\right) \cdot \rho_{\mathrm{Soil}}(645)}$.

Similar to the work by von Hoyningen-Huene et al. (2011), an air mass- corrected aerosol reflectance factor

$\rho_{\text {Aer_ac }}=\rho_{\text {Aer }} \frac{0.5 \cdot M\left(z_{0}\right)+1.5 \cdot M\left(z_{\mathrm{s}}\right)}{M\left(z_{0}\right)^{0.5} \cdot M\left(z_{\mathrm{s}}\right)^{1.5}}$

has been introduced. Note that this parameter was here weighted to account for the larger viewing angle of MODIS compared to MERIS and should be considered as preliminary, since it is still under investigation.
Finally, AOT is determined according to lookup tables (LUTs) that describe the relationship between aerosol reflectance and AOT. The LUTs were obtained from radiativetransfer calculations using the aerosol phase function, single scattering albedo (equal to 0.98) and spectral surface reflectance measured during the LACE-98 experiment (von Hoyningen-Huene et al., 2003). Note that a single scattering albedo of 0.98 represents nearly non-absorbing aerosols. The transmission parameters in Eq. (2) are dependent on AOT. In a first iteration, AOT is calculated based on Rayleigh transmissions only. Later in the process, the iteration converges and stops when the difference between the AOT values, used in the estimation of the transmission parameter and obtained after the LUT has been applied, is lower than 0.01. The Ångström exponent

$\alpha=-\frac{\ln \frac{\tau_{\lambda_{1}}}{\tau_{\lambda_{2}}}}{\ln \frac{\lambda_{1}}{\lambda_{2}}}$

is calculated for the wavelength pair 443 and $665 \mathrm{~nm}$ (Ångström, 1964). This parameter is commonly used to characterize the wavelength dependence of AOT and to provide some basic information on aerosol size (Eck et al., 1999).

A cloud screening approach has been included in the present work. First, a pixel is interpreted as a thick cloud if $\rho_{\mathrm{TOA}}>0.2$ at the wavelengths 469,555 and $645 \mathrm{~nm}$ (Kokhanovsky, 2001). Second, pixels with a ratio of AOT $(443 \mathrm{~nm}) /$ AOT $(469 \mathrm{~nm})<1.08$ between the blue channels are considered as thin clouds due to their significantly reduced Rayleigh scattering component. Third, in order to exclude pixels associated with inhomogeneous clouds, the variability within a $5 \times 5$ pixel masque is investigated. If the ratio between one standard deviation and mean AOT (for values higher than 0.2) is lower than 0.1, the grid box is assumed to be cloud-free. For mean AOT values equal to or lower than 0.2 , the threshold of the ratio is set to 0.3 .

\subsubsection{MODIS c005 algorithm}

In the present study, we use the MODIS c005 level 2 standard products for best quality retrievals (quality flag $=3$ ) over land surfaces reflection ("dark target"). Data have been taken from the NASA Goddard Space Flight Center's Atmosphere Archive and Distribution System (http://ladsweb. nascom.nasa.gov). Here, we will only describe the main features of the method, but a detailed description of the MODIS c005 algorithm can be found in Levy et al. (2007). The MODIS algorithm uses two visible channels ( 0.469 and $0.645 \mu \mathrm{m})$ and one near-infrared band $(2.1 \mu \mathrm{m})$. Note that a vegetated surface is not "dark" at $555 \mathrm{~nm}$, which is why this wavelength cannot be used directly in the MODIS algorithm. The near-infrared channel shows almost no absorption and scatter by gases and aerosols but is highly sensitive to surface reflection. Measurements at $2.1 \mu \mathrm{m}$ are applied together with a consistent spectral relationship that was found for vegetated 
Table 1. Mean aerosol optical thickness (AOT) from AERONET at $440 \mathrm{~nm}$ averaged according to $1 \mathrm{~h}$ (SAER) and $3 \mathrm{~h}$ (MODIS). Relative average absolute deviation (AAD ${ }^{\text {rel }}$, in percent) between AERONET and SAER as well as MODIS $\mathrm{c}_{005}$ for AOT at 443 and $469 \mathrm{~nm}$, respectively, and number of collocations $(N)$ for each AERONET site separately.

\begin{tabular}{lcrrrrrrrr}
\hline Site & Lat. & Long. & Elev. & AOT $_{440}^{1 \mathrm{~h}}$ & $\mathrm{AAD}_{443}^{\mathrm{rel}}$ & $N_{443}$ & $\mathrm{AOT}_{440}^{3 \mathrm{~h}}$ & $\mathrm{AAD}_{469}^{\text {rel }}$ & $N_{469}$ \\
\hline SMHI & $58.59^{\circ} \mathrm{N}$ & $17.47^{\circ} \mathrm{E}$ & $25.0 \mathrm{~m}$ & $0.45 \pm 0.26$ & 23 & 15 & $0.37 \pm 0.22$ & 6 & 18 \\
Toravere & $58.25^{\circ} \mathrm{N}$ & $26.46^{\circ} \mathrm{E}$ & $70.0 \mathrm{~m}$ & $0.35 \pm 0.26$ & 27 & 72 & $0.34 \pm 0.25$ & 9 & 72 \\
Minsk & $53.92^{\circ} \mathrm{N}$ & $27.60^{\circ} \mathrm{E}$ & $200.0 \mathrm{~m}$ & $0.61 \pm 0.42$ & 18 & 28 & $0.56 \pm 0.38$ & 11 & 28 \\
Hamburg & $53.57^{\circ} \mathrm{N}$ & $9.97^{\circ} \mathrm{E}$ & $105.0 \mathrm{~m}$ & $0.37 \pm 0.31$ & 23 & 57 & $0.38 \pm 0.28$ & 12 & 58 \\
Cabauw & $51.97^{\circ} \mathrm{N}$ & $4.93^{\circ} \mathrm{E}$ & $-0.7 \mathrm{~m}$ & $0.33 \pm 0.19$ & 29 & 29 & $0.29 \pm 0.10$ & 20 & 29 \\
Belsk & $51.84^{\circ} \mathrm{N}$ & $20.79^{\circ} \mathrm{E}$ & $190.0 \mathrm{~m}$ & $0.44 \pm 0.37$ & 22 & 56 & $0.44 \pm 0.32$ & 11 & 57 \\
IFT-Leipzig & $51.35^{\circ} \mathrm{N}$ & $12.44^{\circ} \mathrm{E}$ & $125.0 \mathrm{~m}$ & $0.38 \pm 0.17$ & 13 & 12 & $0.38 \pm 0.16$ & 9 & 13 \\
Dunkerque & $51.04^{\circ} \mathrm{N}$ & $2.37^{\circ} \mathrm{E}$ & $0.0 \mathrm{~m}$ & $0.52 \pm 0.27$ & 23 & 16 & $0.38 \pm 0.25$ & 16 & 17 \\
Mainz & $50.00^{\circ} \mathrm{N}$ & $8.00^{\circ} \mathrm{E}$ & $150.0 \mathrm{~m}$ & $0.37 \pm 0.18$ & 33 & 32 & $0.33 \pm 0.17$ & 15 & 38 \\
Karlsruhe & $49.09^{\circ} \mathrm{N}$ & $8.43^{\circ} \mathrm{E}$ & $140.0 \mathrm{~m}$ & $0.26 \pm 0.14$ & 22 & 25 & $0.33 \pm 0.22$ & 20 & 28 \\
Paris & $48.87^{\circ} \mathrm{N}$ & $2.33^{\circ} \mathrm{E}$ & $50.0 \mathrm{~m}$ & $0.41 \pm 0.21$ & 27 & 13 & $0.42 \pm 0.20$ & 18 & 14 \\
Palaiseau & $48.70^{\circ} \mathrm{N}$ & $2.21^{\circ} \mathrm{E}$ & $156.0 \mathrm{~m}$ & $0.28 \pm 0.16$ & 29 & 20 & $0.34 \pm 0.17$ & 11 & 21 \\
Fontainebl. & $48.41^{\circ} \mathrm{N}$ & $2.68^{\circ} \mathrm{E}$ & $85.0 \mathrm{~m}$ & $0.25 \pm 0.15$ & 24 & 13 & $0.30 \pm 0.17$ & 15 & 13 \\
Munich Un. & $48.15^{\circ} \mathrm{N}$ & $11.57^{\circ} \mathrm{E}$ & $533.0 \mathrm{~m}$ & $0.24 \pm 0.10$ & 19 & 9 & $0.25 \pm 0.12$ & 14 & 9 \\
Laegeren & $47.48^{\circ} \mathrm{N}$ & $8.35^{\circ} \mathrm{E}$ & $735.0 \mathrm{~m}$ & $0.26 \pm 0.10$ & 32 & 19 & $0.26 \pm 0.11$ & 18 & 18 \\
Moldova & $47.00^{\circ} \mathrm{N}$ & $28.82^{\circ} \mathrm{E}$ & $205.0 \mathrm{~m}$ & $0.40 \pm 0.27$ & 20 & 22 & $0.35 \pm 0.23$ & 18 & 26 \\
Ispra & $45.80^{\circ} \mathrm{N}$ & $8.63^{\circ} \mathrm{E}$ & $235.0 \mathrm{~m}$ & $0.42 \pm 0.15$ & 17 & 17 & $0.36 \pm 0.13$ & 17 & 17 \\
Modena & $44.63^{\circ} \mathrm{N}$ & $10.94^{\circ} \mathrm{E}$ & $56.0 \mathrm{~m}$ & $0.59 \pm 0.15$ & 14 & 5 & $0.50 \pm 0.21$ & 11 & 6 \\
Villefranche & $43.68^{\circ} \mathrm{N}$ & $7.33^{\circ} \mathrm{E}$ & $130.0 \mathrm{~m}$ & $0.48 \pm 0.14$ & 30 & 8 & $0.39 \pm 0.13$ & 17 & 10 \\
Le Fauga & $43.38^{\circ} \mathrm{N}$ & $1.28^{\circ} \mathrm{E}$ & $193.0 \mathrm{~m}$ & $0.31 \pm 0.09$ & 45 & 14 & $0.28 \pm 0.10$ & 24 & 14 \\
\hline
\end{tabular}

land surface (Kaufman et al., 1997) to estimate the surface reflection at 0.469 and $0.645 \mu \mathrm{m}$ wavelength. Note that the surface-reflectance relationship is empirical and established according to $4 \mathrm{yr}$ of co-located MODIS and AERONET data. Furthermore, wavelengths in other parts of the spectrum are used to filter non-dark-target conditions, such as deserts as well as snow and ice surfaces (Ackerman et al., 1998; Li et al., 2005). A single scattering albedo of 0.95 (representing weakly absorbing aerosols) is used for the area investigated in this study (Europe). MODIS level 2 aerosol products are provided with a horizontal resolution of approximately $10 \mathrm{~km}$. However, spectral observations are performed with a horizontal resolution of $500 \mathrm{~m}$ that is also used for cloud screening (Gao et al., 2002; Martins et al., 2002). The pixels that remain in a $10-\mathrm{km}^{2}$ box after cloud screening are sorted according to their relative reflectance (at $0.66 \mu \mathrm{m}$ ), and $20 \%$ and $50 \%$ of the darkest and brightest pixels, respectively, are removed. This means that at most $120(30 \%)$ and at least $12(3 \%)$ out of the original 400 pixels remain for further processing. All accepted pixels are averaged to obtain a single set of spectral reflectances that is used to retrieve the level 2 aerosol products. The AOT retrieved at the wavelengths 469 and $645 \mathrm{~nm}$ is used for the calculation of $\alpha$ according to Eq. (7).

\subsection{AOT from AERONET sun photometers}

The satellite retrievals of AOT have been validated against AERONET level 2.0 data (quality assured) for the sites

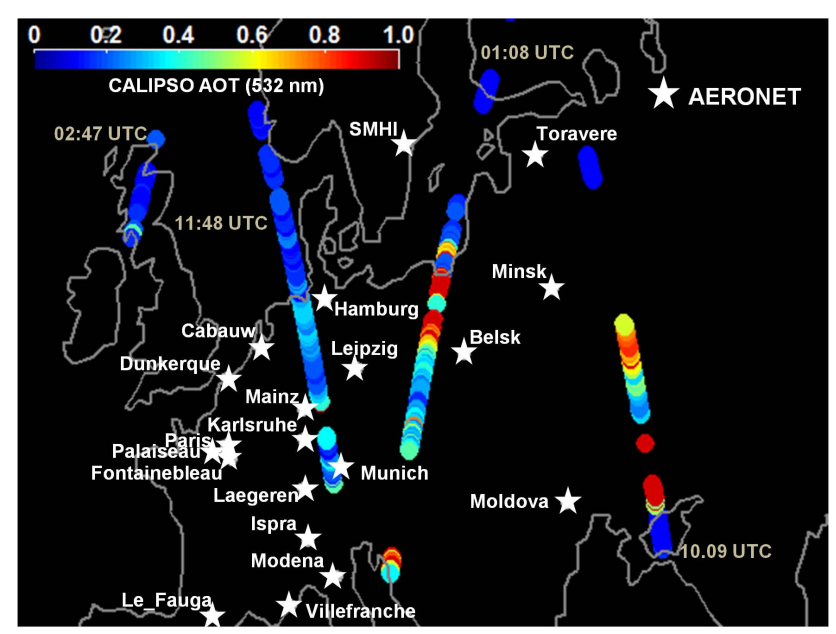

Fig. 1. Location of the AERONET stations used in the present study. The colored dots represent AOT at $532 \mathrm{~nm}$, obtained from CALIPSO measurements during day and night tracks on 1 April 2007. The approximate overpass times are provided for the individual tracks. AOTs are only shown for cases without clouds in the profile and for which a ground signal was detected.

shown in Fig. 1 and Table 1. Information about the Cimel sun photometers operated at these sites can be found at http://aeronet.gsfc.nasa.gov. AERONET data used for the present study include AOT at 440 and $500 \mathrm{~nm}$ as well as $\alpha(440 / 675 \mathrm{~nm})$. These values were recorded every $15 \mathrm{~min}$ 

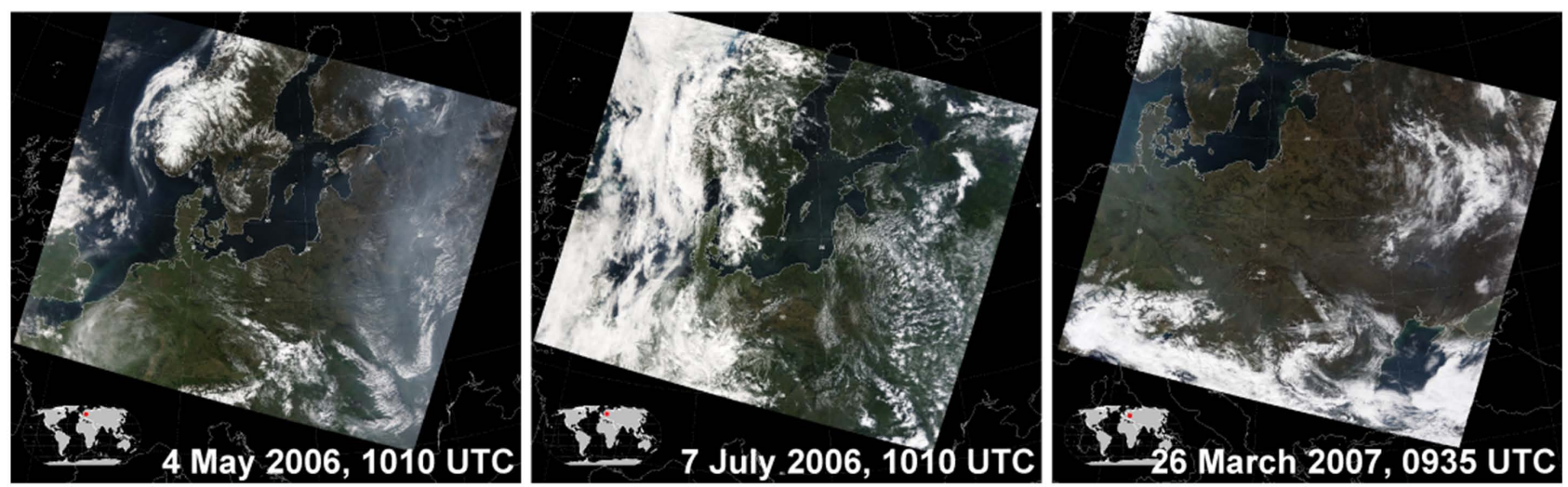

Fig. 2. MODIS visible composite pictures over Europe for (a) 4 May 2006, (b) 7 July 2006 and (c) 26 March 2007.

and automatically cloud screened (Smirnov et al., 2000). AERONET-derived estimates of spectral AOT are expected to be accurate within \pm 0.02 (e.g. Holben et al., 1998).

\subsection{Statistical approach used to evaluate comparisons of AOT}

The coefficient of determination $\left(R^{2}\right)$, the average absolute deviation (AAD), and the relative $\mathrm{AAD}\left(\mathrm{AAD}^{\text {rel }}\right)$ were determined for collocated satellite and AERONET-averaged values by means of a linear regression. The AAD and relative $\mathrm{AAD}$ are defined as

$\mathrm{AAD}=\sum_{i=1}^{N} \frac{\left|x_{i}-\bar{x}\right|}{N}$

and

$\mathrm{AAD}^{\mathrm{rel}}=\frac{\mathrm{AAD}}{[\overline{\mathrm{AOT}(1)}+\overline{\mathrm{AOT}(2)}] / 2}$

where

$$
\begin{gathered}
x_{i}=\operatorname{AOT}(1)_{i}-\operatorname{AOT}(2)_{i}, i=1, \ldots \ldots, N \\
\bar{x}=\frac{1}{N} \sum_{i=1}^{N} x_{i} .
\end{gathered}
$$

The index $i$ refers to collocated matches, where AOT(1) and AOT(2) either represent SAER and MODIS c005 retrievals or one of the latter and AERONET observations, with the total number $N$ of such pairs. Particularly when performing satellite retrievals of aerosol optical properties over land, large outliers are expected (Kahn et al., 2011). The AAD does not weight larger outliers to the same degree as the root mean square deviation, and therefore this statistical approach has been used in the present study.

\section{Results of AOT over Europe}

The aerosol optical properties over Europe as retrieved with the two algorithms and measured by AERONET have been investigated for three time periods; 1-10 May 2006 (period 1), 1-14 July 2006 (period 2) and 26 March1 April 2007 (period 3). Periods 1 and 3 were both influenced by high pressure systems, estimated by the European Centre for Medium-Range Weather Forecasts (ECMWF), with cores mainly located over Finland and eastern Ukraine/southern Russia, respectively (not shown). Such a weather situation favors the accumulation of aerosols from local sources but also enables long-range transport from sources to the east of the investigation area. Figure 2 shows visible composites from MODIS observations as an example for the meteorological conditions during the periods investigated. Periods 1 and 3 were associated with lower amount of clouds present over central Europe than for the two weeks in July 2006, also representative when the whole periods are considered (not shown). Periods 1 and 3 were further strongly influenced by aerosols that originated from agricultural fires in Ukraine and Russia (Stohl et al., 2007; Cook et al., 2008) as is visible in the cloud-free areas on the right and left parts of Fig. 2a and c, respectively.

\subsection{Case study}

Figure 3 shows 555-nm AOT, retrieved with the SAER and MODIS c005 algorithms, for two MODIS Aqua overpasses over Europe at 10:45 and 12:20 UTC on 1 April 2007. For this, the pixel-by-pixel comparison means that the findings obtained with SAER were averaged to match the MODIS c005 resolution of $10 \times 10 \mathrm{~km}^{2}$. The enhanced AOT values are caused by aerosols from agricultural fires over Ukraine and Russia (Cook et al., 2008). On the whole, good agreement is found between the results obtained with the two algorithms, particularly for land areas associated with high aerosol loadings. This is confirmed by the statistics for 14507 co-located pixels over land that is shown in Fig. 3a. Retrievals over water have not been analyzed here, but will be the focus in subsequent investigations. However, Fig. 3 also shows that relatively large discrepancies in AOT occur over parts of the investigation area, e.g. southern Sweden and 

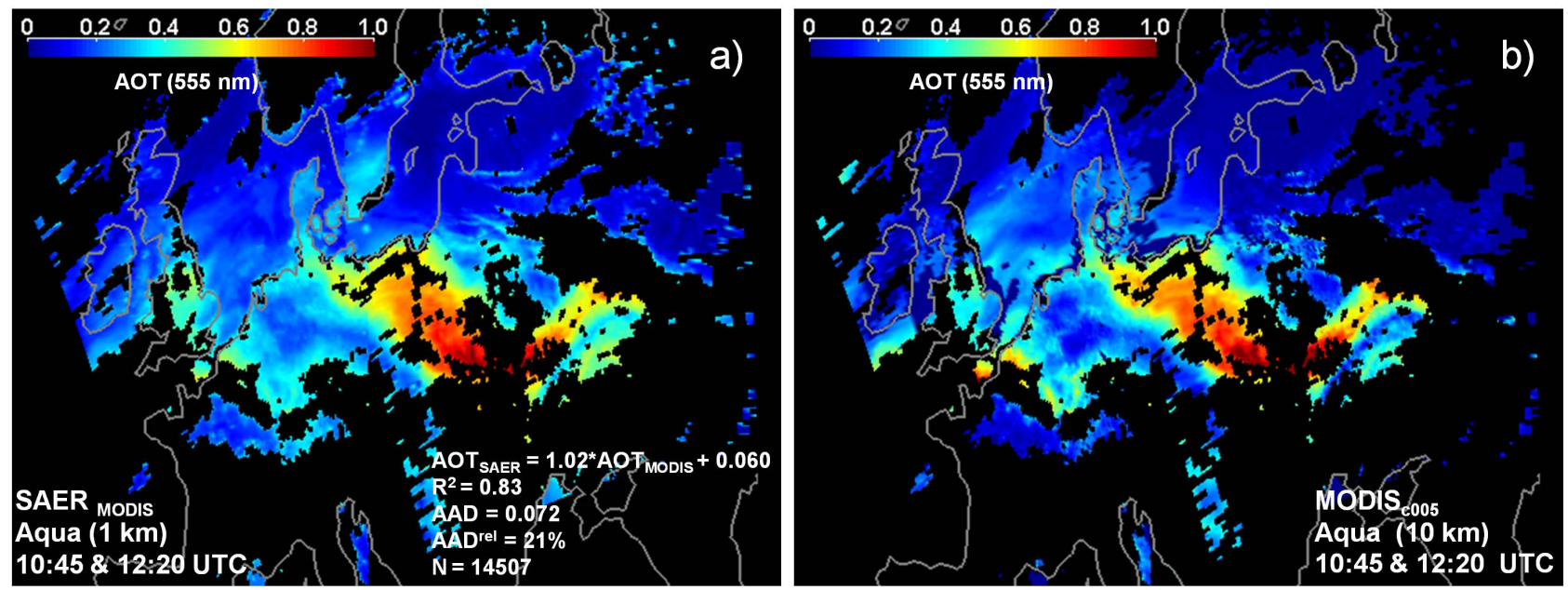

Fig. 3. Aqua satellite scenes of AOT at $555 \mathrm{~nm}$ over land and water surfaces in Europe for a combination of two overpasses at 10:45 and 12:20 UTC on 1 April 2007 obtained with (a) the SAER algorithm and (b) the MODIS c005 algorithm. The expression for the linear regression curve was calculated based only on co-located land pixels and without binning the data. The explanation of abbreviations is given in Sect. 2.3.

west of the Gulf of Finland. The enhanced values over the latter area, provided by the SAER retrieval shown in Fig. 3a, are probably caused by improper cloud screening of these satellite pixels.

Besides the findings from MODIS observations in Fig. 3, 532-nm AOT derived from measurements of the lidar aboard the Cloud Aerosol Lidar and Infrared Pathfinder Satellite Observations (CALIPSO, Winker et al., 2009) satellite for four overpasses over Europe on 1 April 2007 is also shown in Fig. 1. Even though the CALIPSO swath is much narrower than the one of MODIS, similar values are obtained in the areas associated both with high and low aerosol loadings. An exception is given for the southern Ukraine where MODIS classified the area as cloudy, while CALIPSO gives AOTs close to 1 . MODIS visible composite suggests that clouds actually are formed in this area. However, CALIPSO measurements allow for cloud screening of individual profiles, and level 2 data are provided with a horizontal resolution of $5 \mathrm{~km}$. Note also that a comparison of AOT from CALIPSO and MODIS should be considered as qualitative, since the CALIPSO level 2 column AOT product is not intended for scientific use. CALIPSO measurements close to Belsk at 01:08 UTC on 1 April 2007 give extinction coefficients of about $0.4 \mathrm{~km}^{-1}$ within a homogeneous layer from the surface up to $2.3 \mathrm{~km}$ (not shown). The resulting 532-nm AOT of about 0.9 agrees well with measurements of the AERONET sun photometer. The highest AOT values at $555 \mathrm{~nm}(>0.8)$ shown in Fig. 6 were observed at Belsk at 09:00 UTC during this day.

\subsection{Validation against AERONET}

For a proper comparison of satellite- and ground-based observations, the Ångström power law (Eq. 7) was used to convert AERONET AOT (at 440 and $500 \mathrm{~nm}$ ) to the wavelengths 469 and $555 \mathrm{~nm}$ (MODIS c005) as well as 443 and $488 \mathrm{~nm}$ (SAER). Findings of the satellite retrievals were averaged over at most 9 and 25 cloud-free pixels for MODIS c005 and SAER, respectively, adjacent to and including the pixel that corresponds to a ground site. This means that the outputs of the SAER and MODIS c005 retrievals were averaged according to a maximum area of 5 and $30 \mathrm{~km}^{2}$, respectively. As a consequence and to account for these different horizontal resolutions, AERONET measurements for comparison were averaged over time periods of $1 \mathrm{~h}$ (SAER) and $3 \mathrm{~h}$ (MODIS c005) at longest around individual satellite overpasses. According to these criteria, only cases that are associated with at least two cloud-free satellite pixels and two AERONET AOT measurements were considered for comparison. However, generally the number of pixels averaged both for the SAER and MODIS c005 retrievals is close to the maximum numbers (not shown). A comparison of MODIS visible composite pictures (not shown) generally shows higher cloud cover for overpasses of Aqua compared to the earlier ones of Terra.

\subsubsection{MODIS c005 AOT and $\alpha$}

Figure 4 shows comparison of AOT at $469 \mathrm{~nm}$, retrieved with the MODIS c005 algorithm and measured at the AERONET stations (Fig. 1 and Table 1) during the considered time periods. The comparison is separated according to MODIS measurements aboard the Aqua and Terra satellites. On the whole, the AOT is within the expected uncertainties of 

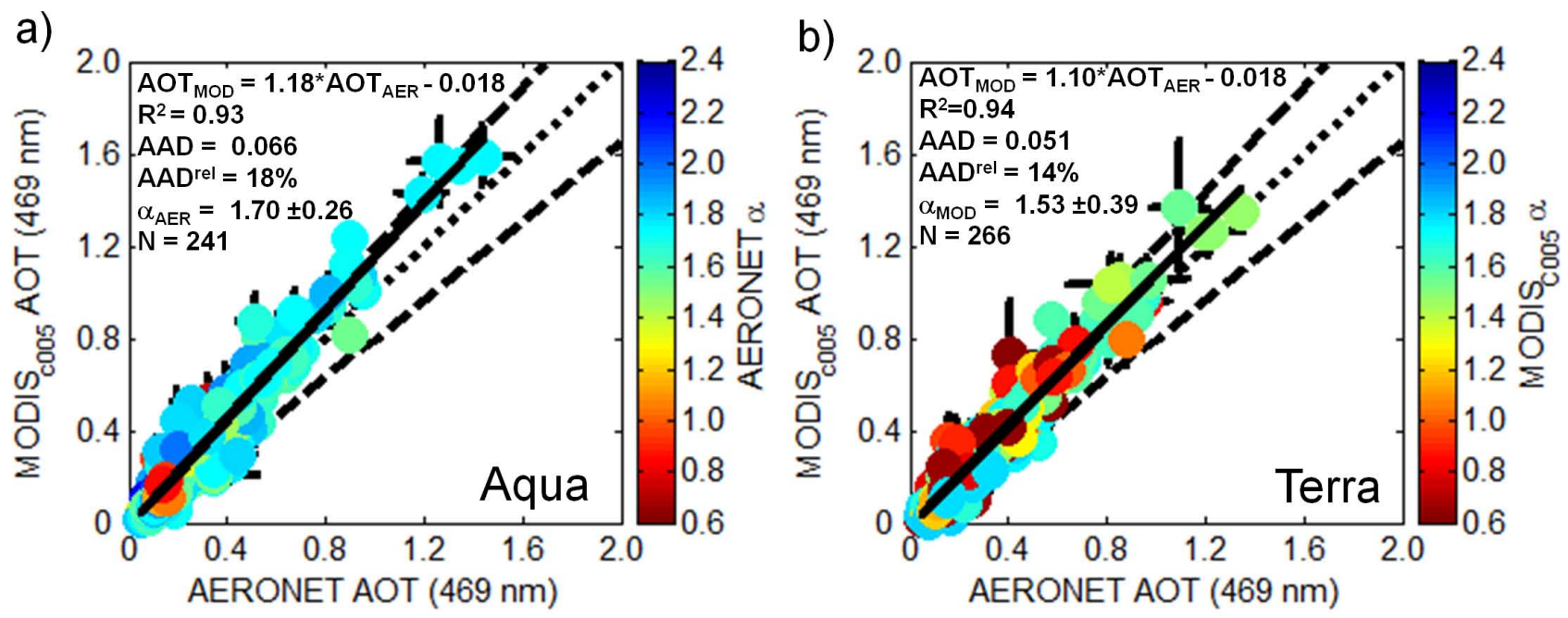

Fig. 4. Comparison between MODIS c005 and AERONET AOT at $469 \mathrm{~nm}$ for overpasses of (a) Aqua and (b) Terra during the time periods investigated here. The color code refers to $\alpha$ as obtained with AERONET and MODIS for the wavelength pairs 440/675 and 469/645 nm, respectively. The solid, dashed and dotted lines represent linear fits, expected uncertainties for one standard deviation of the MODIS c005 aerosol retrievals and 1-to-1 line, respectively. The median Ångström exponent $(\alpha)$ and corresponding one standard deviation are given. The explanation of abbreviations is given in Sect. 2.3.

one standard deviation of the MODIS retrievals over land $(\triangle \mathrm{AOT}= \pm 0.05 \pm 0.15 \cdot$ AOT, Levy et al., 2010), although somewhat higher MODIS values are found compared to AERONET. The largest $\mathrm{AAD}^{\text {rel }}$ occurs for period 2 (not shown), which is associated with more clouds present than the other two time periods (Sect. 3). The findings in Fig. 4 confirm the high quality of the results of the MODIS c005 retrieval over dark land surface that was also found by Levy et al. (2010) for a global data set. Furthermore, the high values of $\alpha$ obtained from the AERONET measurements (color coded in Fig. 4a) suggest a dominance of submicron aerosols over Europe during the time periods investigated. Median values of MODIS c005 $\alpha(469 / 645 \mathrm{~nm})$ and AERONET $\alpha$ $(440 / 675 \mathrm{~nm})$ and corresponding one standard deviation are also given in Fig. 4a and b, respectively. The figures indicate that large discrepancy in $\alpha$ occurs, which is more clearly shown in Fig. 5 where comparisons of the absolute values are presented for the time periods investigated. The large discrepancy is probably due to the fact that even small errors in AOT amplify substantially in the calculation of $\alpha$ according to Eq. (7).

Figure 5 shows AOT at $555 \mathrm{~nm}$, also estimated with the MODIS algorithm and observed at the AERONET stations during the time periods investigated. The good agreement is confirmed when considering this wavelength. However, as for the $469 \mathrm{~nm}$, an overestimation of MODIS AOT at $555 \mathrm{~nm}$ occurs here as well. Note that the comparison is for this wavelength based on less collocation, since AOT at $500 \mathrm{~nm}$ was not measured at some of the AERONET stations that are included in the present study.

\subsubsection{SAER AOT and $\alpha$}

A comparison of AOT at $443 \mathrm{~nm}$, retrieved with SAER and measured with AERONET, comparable to the one presented in the previous section, is shown in Fig. 7. Relatively good agreement is found, but, in general, larger $\mathrm{AAD}^{r e l}$ values appear compared to the results obtained with the MODIS c005 algorithm. In addition, lower and more widespread values of $\alpha$ are obtained with the SAER algorithm compared to MODIS c005 and AERONET. A comparison between AOT from SAER and AERONET was also performed for the $488 \mathrm{~nm}$ wavelength. Figure 8 shows that a substantially larger discrepancy in AOT was found at this wavelength compared to the comparison performed according to the shorter wavelength. The larger deviation is probably due to higher surface reflection for longer wavelengths within the solar spectrum (von Hoyningen-Huene et al., 2003), which increases the sensitivity of the SAER AOT retrieval. This explains the larger discrepancy. This probably also explains the larger discrepancy in $\alpha$ that was found with the SAER compared to the results obtained with the MODIS c005 algorithm. Note that Figs. 7 and 8 indicate that the slope of the regression line for the SAER is somewhat steeper for Aqua than Terra at both wavelengths, similar to the results obtained with the MODIS c005 algorithm.

\subsubsection{Comparison between satellite retrievals and AERONET at each site}

Table 1 shows comparison between satellite retrievals and AERONET observations for each ground-based station according to the methodology described in Sect. 3.2. The table 

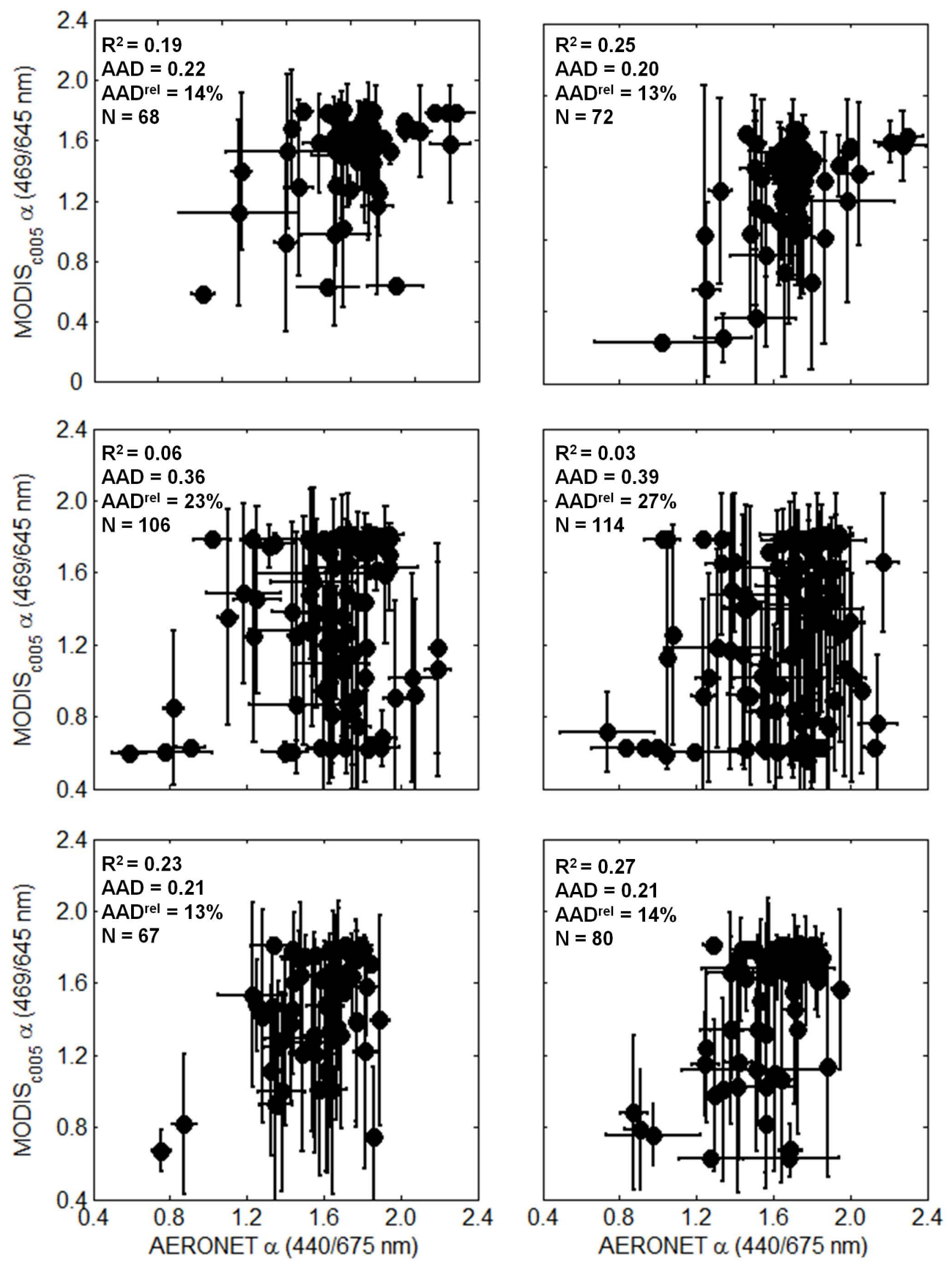

Fig. 5. Comparisons between MODIS c005 and AERONET $\alpha$ for the wavelength pairs 469/645 and 440/675 nm, respectively, according to Aqua (left column) and Terra (right column) and period 1 (top panels), 2 (middle panels) and 3 (bottom panels). The explanation of abbreviations is given in Sect. 2.3.

shows that the number of SAER retrievals is lower than that of MODIS for several of the AERONET sites, which is probably explained by cloud screening in the SAER algorithm. Note that with the MODIS c005 approach a $10 \mathrm{~km}$ box is represented by at most $30 \%$ of cloud-free pixels, but could also be as low as $3 \%$. Furthermore, by comparing AERONET AOT $(440 \mathrm{~nm})$ averaged according to $1 \mathrm{~h}$ and $3 \mathrm{~h}$ for the SAER and MODIS retrievals, respectively, a relatively large difference is found for several of the sites. This may be explained by the averaging of AOT, which has been performed then according to difference in length of the time, and for some of the cases also with difference in $N$. Table 1 shows also that lower discrepancies between satellite retrievals and AERONET observations occur as expected for the MODIS c005 algorithm compared to the SAER. The largest deviations in AOT retrieved with 


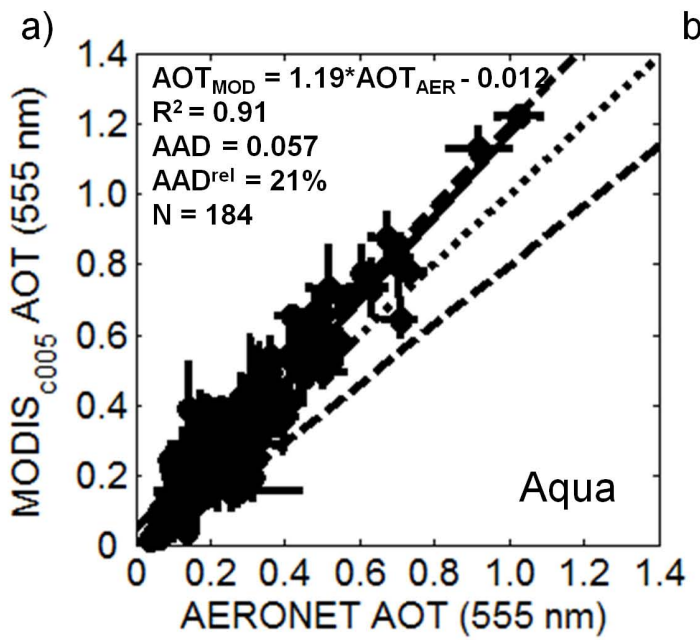

b)

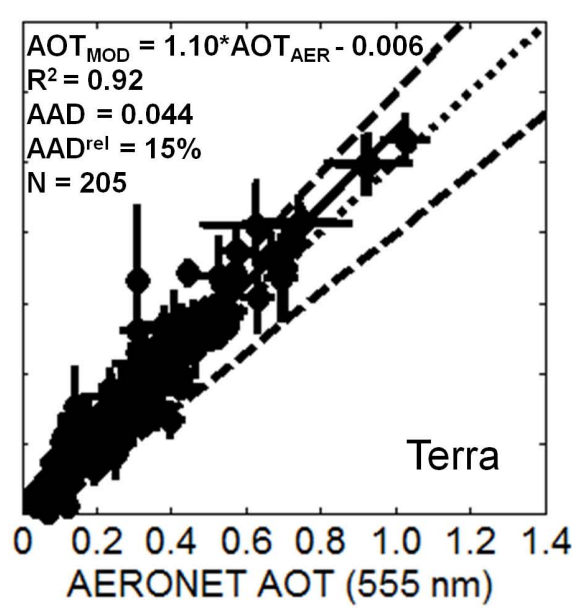

Fig. 6. Comparison between MODIS c005 AOT and AERONET AOT at $555 \mathrm{~nm}$ for (a) Aqua and (b) Terra and the time periods investigated. The solid, dashed and dotted lines represent linear fits, expected uncertainties for one standard deviation of the MODIS c005 aerosol retrievals and 1-to-1 line, respectively. The explanation of abbreviations is given in Sect. 2.3.
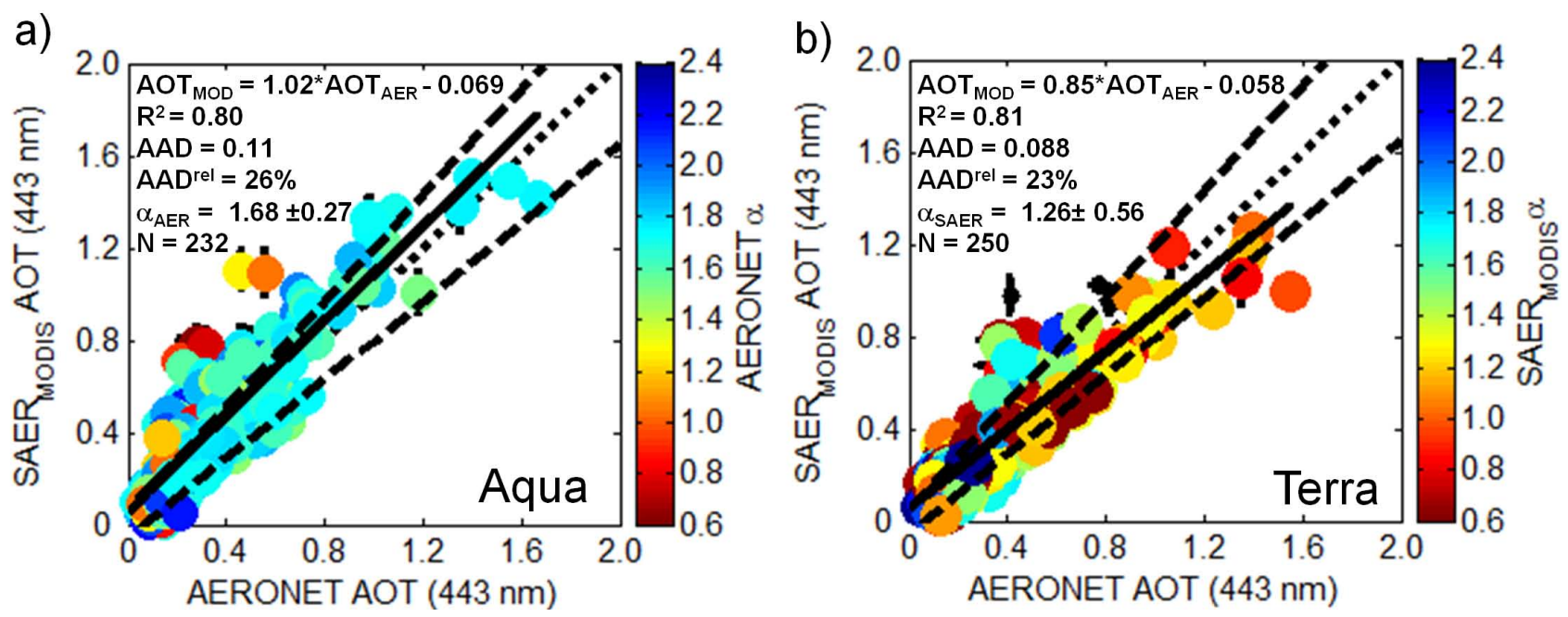

Fig. 7. Same as Fig. 4 but for a comparison of SAER MODIS and AERONET AOT at $443 \mathrm{~nm}$ and the color coding in (b) refers to $\alpha$ as obtained with SAER MODIS for the wavelength pair $443 / 645 \mathrm{~nm}$.

SAER compared to AERONET are found for the sites Mainz, Laegeren, Villefrance and Le Fauga, while for MODIS c005 and AERONET the largest deviations occur for Cabauw, Karlsruhe and Le Fauga.

\subsection{Inter-comparison between SAER and MODIS}

Figure 9 shows an inter-comparison of 469-nm AOT as retrieved with SAER and the operational MODIS c005 algorithm. To compile the figure, AOT derived with SAER was averaged according to the MODIS pixel resolution of $10 \times 10 \mathrm{~km}^{2}$. Relatively good agreement is found between the two algorithms, although values of AOT obtained with SAER are systematically lower than the ones obtained with the MODIS algorithm for high aerosol loading. This can be seen particularly for Terra corresponding to period 2 (Fig. 9d). For AOT smaller than 1, results obtained with the SAER algorithm are well within the expected uncertainty of one standard deviation of the MODIS retrieval for both Aqua and Terra corresponding to periods 1 and 3 . The same good agreement is also found for Aqua and period 2, but only for AOT values lower than 0.5 . Part of the discrepancy that is obtained between SAER and MODIS c005 (shown in Fig. 9) could indeed be due to clouds that are not screened out correctly by the former algorithm (Sect. 3.1). Note that the figures indicate that the slope of the regression line is on the whole steeper for Aqua compared to Terra. In the previous sections, it was shown that this also occurs when SAER as 


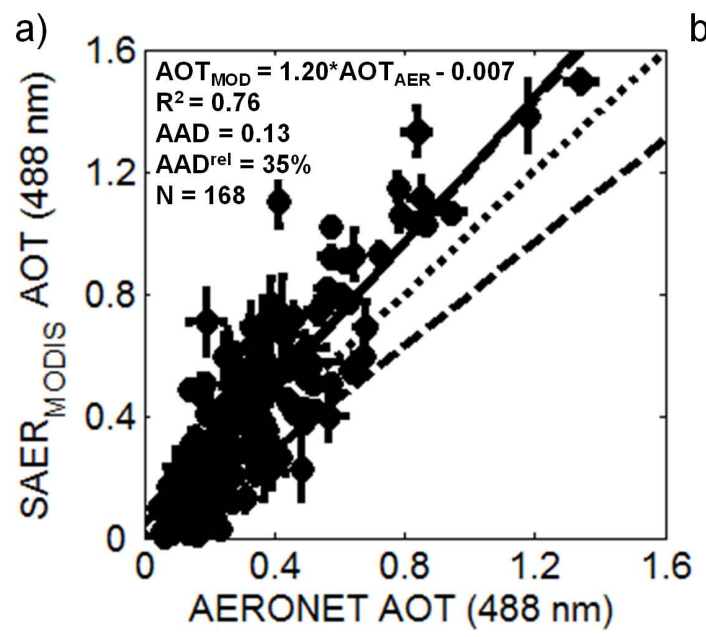

b)

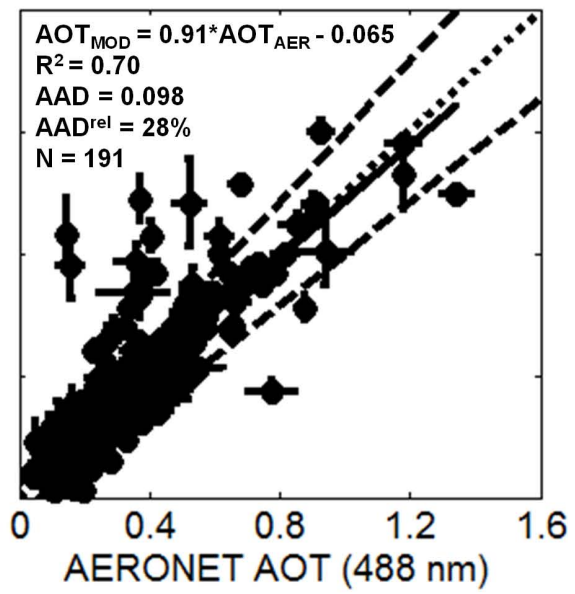

Fig. 8. Same as Fig. 6 but for a comparison of SAER MODIS and AERONET AOT at $488 \mathrm{~nm}$.

well as MODIS c005 are compared to AERONET observations, although somewhat steeper slope is found in the former comparison. The overpasses of Aqua on the whole occurred after that Terra passed the investigation area, which means that a difference in the sun elevation associated with the two platforms is expected. Thus, the treatment of the sun-zenith satellite-viewing geometry may cause the deviation found.

\subsection{Discussion}

The inter-comparison of the findings of MODIS c005 and SAER retrievals and the validation of these algorithms against AERONET measurements suggests that a small part of the deviation found for high aerosol loadings seems to be due to a general overestimation of AOT by the operational MODIS algorithm. From the substantially larger $A_{A} D^{\text {rel }}$ for the comparison of findings of the SAER retrieval with AERONET measurements (Fig. 7), with respect to the one found for MODIS c005 and AERONET (Fig. 4), it can be concluded, however, that a major part of the discrepancy presented in Fig. 9 is probably caused by uncertainties in the SAER approach. For a better view on this effect, Fig. 10a and $b$ show the comparison of the findings of the two algorithms for two individual Terra overpasses at 09:00 and 10:40 UTC, respectively, on 1 April 2007. Areas of high aerosol loadings appear (not shown) near the western edge (09:00 UTC overpass) and center (10:40 UTC overpass) of the respective satellite scenes and, thus, fall together with a difference in the elevation of the sun and an even larger disparity in the sensor's viewing angle (Sect. 2.1). Thus, the treatment of the sun-zenith satellite-viewing geometry in the SAER retrieval is most likely responsible for a major part of the discrepancy shown in Figs. 9 and 10, particularly for situations with high aerosol loading. This is also confirmed when the satellite retrievals are compared to AERONET measurements. While AERONET AOT varied marginally at the Belsk station between the two satellite overpasses (1.02 and 1.07 , respectively), the SAER AOT varies by approximately 0.3 at MODIS values around 1 (shown in Fig. 10). A similarly large difference in AOT $(\sim 0.3)$ is also obtained for high aerosol loadings when SAER is applied to the two MODIS Aqua overpasses on 1 April 2007 (not shown). Additionally, the larger deviation that occurs between SAER and AERONET AOT at green wavelengths compared to blue wavelengths may be explained by a higher sensitivity of the satellite retrievals for longer wavelengths. This is because the surface reflection increases substantially for longer wavelength within the solar spectrum (von Hoyningen-Huene et al., 2003).

Poor agreement between SAER and AERONET was found for $\alpha$. Poor agreement was also found between values of $\alpha$ obtained from MODIS c005 and AERONET, which is somewhat surprising considering that good agreement was found for the AOT retrieved with the two platforms at blue and green wavelengths. However, the uncertainties in the estimates of AOT at two different wavelengths have a large impact on the calculation of $\alpha$ according to Eq. (7). Levy et al. (2010) also found poor agreement in $\alpha$ when comparing MODIS c005 and AERONET, and concluded that this parameter has little global quantitative value.

\section{Summary and conclusions}

Findings of AOT and $\alpha$ from satellite retrievals with the MODIS c005 and SAER algorithms, applied to data collected from the MODIS Aqua and Terra sensors over Europe, were inter-compared and validated against AERONET measurements. Comparisons were performed for a total of 31 days in three distinct periods in spring and summer that were found most suitable due to their persistent low cloud cover. For several of the cases analyzed here, the Aqua and 
a)

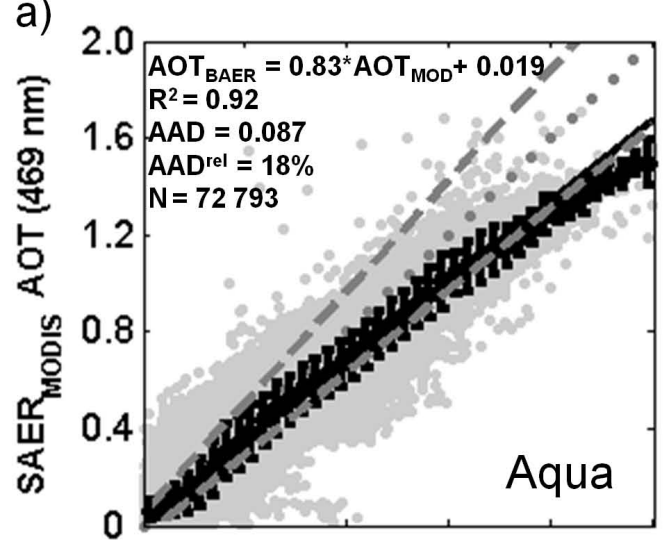

c)

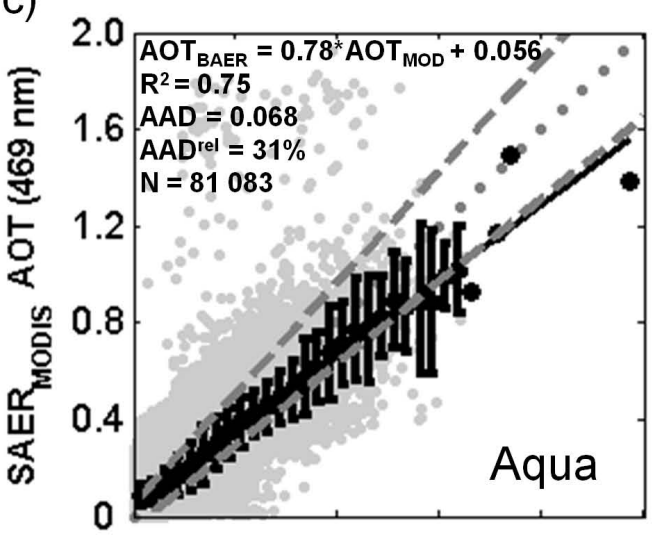

e)

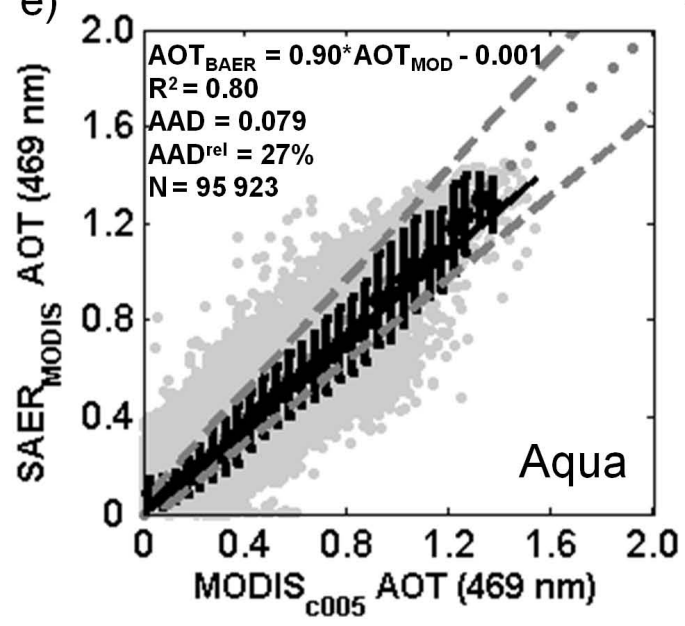

b)

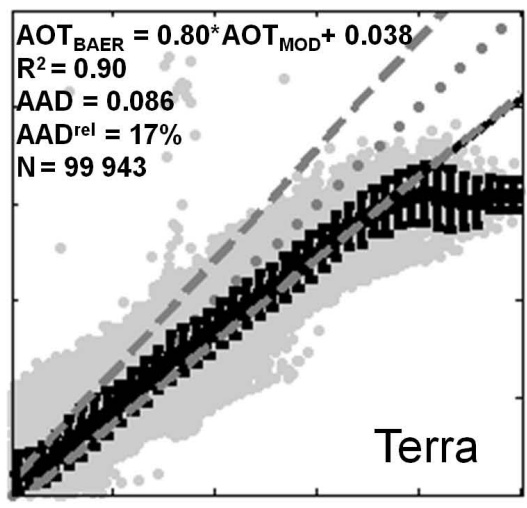

d)

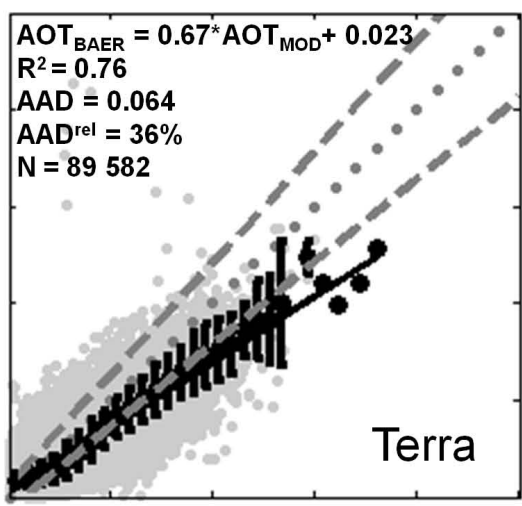

f)

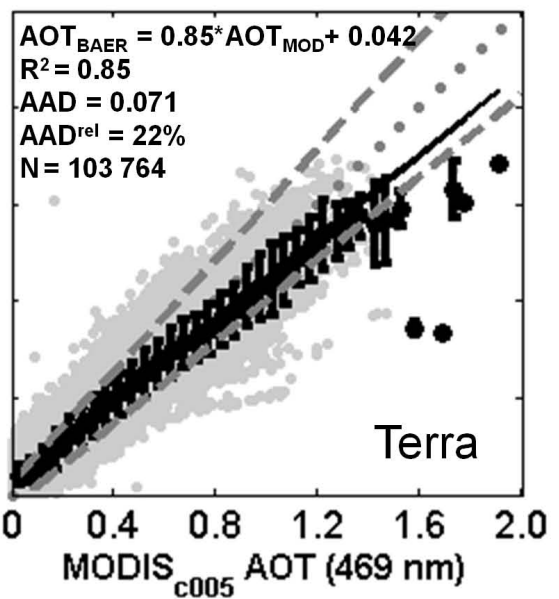

Fig. 9. Pixel-by-pixel $(10 \mathrm{~km})$ comparison of SAER and MODIS c005 AOT over land surfaces in Europe according to Aqua (left column) and Terra (right column) and period 1 (top panels), 2 (middle panels) and 3 (bottom panels). Black dots and error bars denote mean AOT values in intervals of 0.05 and the corresponding one standard deviation, respectively. The solid black, dashed and dotted grey lines represent linear fits, expected uncertainties for one standard deviation of the MODIS c005 aerosol retrievals and 1-to-1 line, respectively. The regression equation given in each plot was calculated from the data before binning. The explanation of abbreviations is given in Sect. 2.3 . 

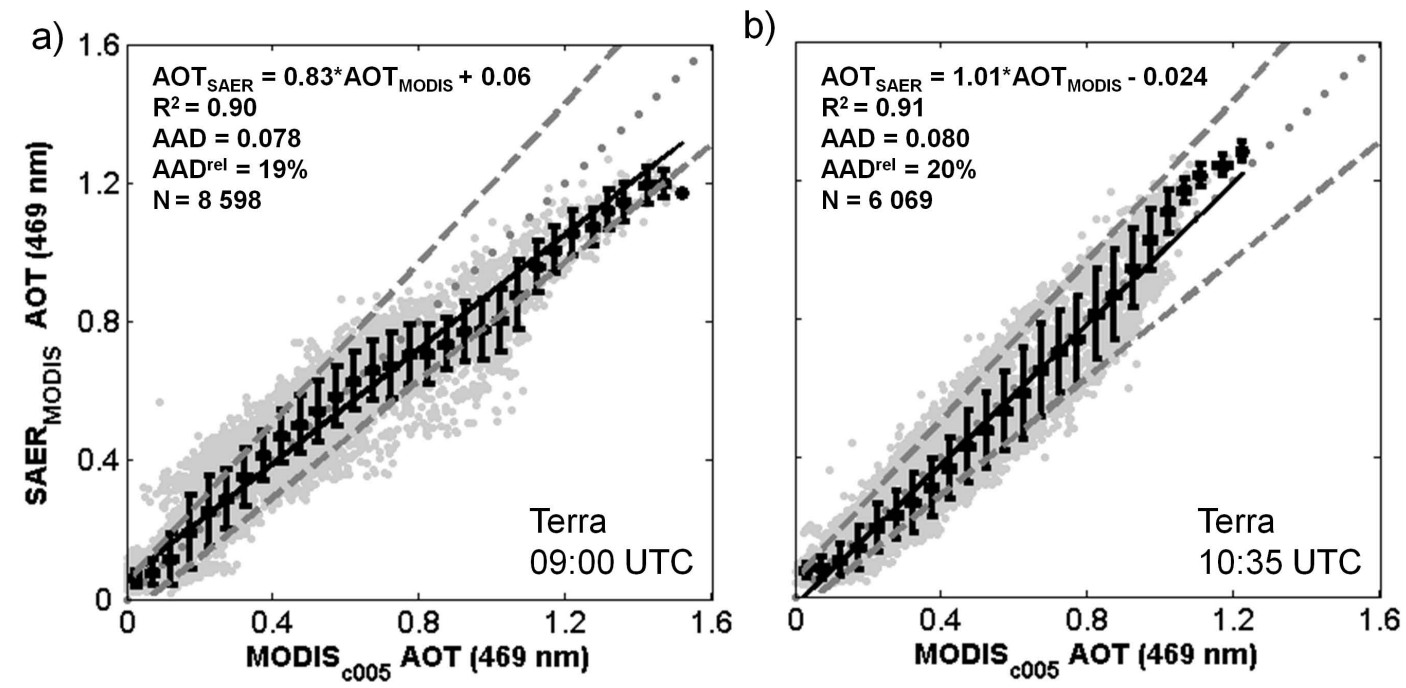

Fig. 10. Same as Fig. 9 but only for two Terra overpasses over Europe on 1 April 2007, at (a) 09:00 UTC and (b) 10:40 UTC.

Terra satellites passed the area investigated twice a day. Besides a variation in the sun elevation between the two overpasses, the satellite retrievals were thus also applied to scenes with a significant variation in the satellite-viewing geometry.

The validation with AERONET measurements for sites in central Europe shows that results of AOT obtained with the MODIS c005 algorithm, for the wavelengths 469 and $555 \mathrm{~nm}$, were generally found to vary within the expected uncertainty for one standard deviation of the MODIS retrievals $(\triangle \mathrm{AOT}= \pm 0.05 \pm 0.15 \cdot \mathrm{AOT})$. The AOT retrieved with the SAER algorithm for the wavelength of $443 \mathrm{~nm}$ also agrees reasonable well with AERONET. Thus, the majority of the SAER values are also within the expected MODIS uncertainty range, although somewhat larger $\mathrm{AAD}^{\text {rel }}$ occurs compared to the MODIS c005 algorithm. The discrepancy between AOT retrieved with SAER compared to AERONET at $488 \mathrm{~nm}$ is however substantially larger; thus, the former values are to a larger extent located outside of the expected MODIS uncertainty range. Both satellite retrieval algorithms are unable to estimate $\alpha$ accurately, although the MODIS c005 algorithm performs better.

Based on the inter-comparison of AOT at $469 \mathrm{~nm}$, retrieved with the SAER and MODIS c005 algorithms, it was found that SAER is able to obtain results within the expected uncertainty range of MODIS for Aqua and Terra observations during periods 1 and 3 as long as AOT does not exceed 1. The same was found for MODIS Aqua observations during period 2 but only for AOT below 0.5. The present results suggest that the deviation that occurs between the two algorithms (i.e. values outside the MODISexpected uncertainty range) and satellite AOT compared to AERONET is most likely caused by the treatment of the sunzenith satellite-viewing geometry in the SAER algorithm. However, the validation of the MODIS c005 algorithm against AERONET measurements suggests that a small part of the deviation found for high aerosol loadings seems to be due to a general overestimation of AOT by MODIS c005. In addition, the comparisons between the two algorithms and AERONET suggest that the satellite-retrieved AOT at the both wavelengths investigated was in general higher for Aqua compared to Terra. The present study suggests that the air mass correction of the column reflectance, introduced as a factor in Eq. (6) for the SAER retrievals, needs further investigation. The same holds for the BRDF suggested by von Hoyningen-Huene et al. (2011), since its introduction did not lead to any improvement of the findings of the aerosol retrievals considered here. The present results suggest also that at least a small part of the discrepancies that occur between the two algorithms is caused by the SAER method used for the cloud screening.

Nevertheless, the overestimation by a factor of 2 in mean AOT, found for low aerosol loadings with the BAER algorithm (Hoyningen-Huene et al., 2006; Glantz et al., 2009a), has substantially been reduced here when SAER of AOT at the blue wavelengths is compared to the AERONET measurements and MODIS c005 retrievals. In addition, better agreement in mean AOT at $443 \mathrm{~nm}$, obtained with the SAER and AERONET sun photometer, was also found considering both Aqua and Terra for high aerosol loadings compared to the previous studies. It can be concluded from this study that satellite retrievals of AOT from MODIS measurements over central Europe, particularly when obtained with the MODIS c005 algorithm, are of very high quality and thus can be used in the validation of regional and climate models. For air quality studies and estimations of particulate matter concentrations in urban environments, highly resolved data are however required (Rohen et al., 2011). From this perspective, such data can be provided by using the SAER 
retrieval instead of the standard MODIS c005 products. Note that the satellite scenes considered here covered a variety of aerosols from marine and continental sources in Europe but also from agricultural fires in Russia and Ukraine. The latter events were associated with high aerosol loadings and AOT beyond 1 , although probably with a single scattering albedo similar to aerosols classified as clean. For the case study presented in Sect. 3.1, active remote sensing observations performed with the CALIPSO lidar were also considered, though not in terms of a detailed discussion. Such data can be used to gain information about the vertical aerosol distribution (i.e. profiles of the aerosol extinction coefficient) and are complementary to the column observations obtained with passive remote sensing. Future studies can provide a much more detailed view of the observed aerosol situation by using a combination of passive (AOT, $\alpha$ ) and active (vertical distribution) remote sensing. Such comprehensive data sets furthermore provide a better foundation for the validation of the treatment of aerosols in regional and climate models than is the case when only using scenes of column-integrated AOT.

Acknowledgements. We thank the PIs of the AERONET sites used in this study for maintaining their stations. We acknowledge the MODIS and CALIPSO mission scientists and associated NASA personnel for the production of the data used in this research effort. The authors are also thankful for the use of ECMWF data sets. The work was financed through research grants from the Swedish Research Council for the Environment, Agricultural Sciences and Spatial Planning (FORMAS).

Edited by: M. Wendisch

\section{References}

Ångström, A.: The parameters of atmospheric turbidity, Tellus, 16, 64-75, 1964.

Ackerman, S. A., Strabala, K. L., Menzel, W. P., Frey, R. A., Moeller, C. C., and Gumley, L. E.: Discriminating clear sky from clouds with MODIS, J. Geophys. Res., 103, 32141-32157, 1998.

Cook, A., Willis, P., Webster, H., and Harrison, M.: UK Air Quality Forecasting: a UK Particulate Episode from 24th March to 2th April 2007, Report AEAT/ENV/R/2566, Issue 1, AEA Technology plc, AEA Energy \& Environment, Oxfordshire, UK, 2008.

Eck, T. F., Holben, B. N., Reid, J. S., Dubovik, O., Smirnov, A., O’Neill, N. T., Slutsker, I., and Kinne, S.: Wavelength dependence of the optical depth of biomass-burning, urban, and desert dust aerosols, J. Geophys. Res., 104, 31333-31349, doi:10.1029/1999JD900923, 1999.

Gao, B., Kaufman, Y. J., Tanré, D., and Li, R.: Distinguishing tropospheric aerosols from thin cirrus clouds for improved aerosol retrievals using the ratio of $1.38 \mu \mathrm{m}$ and $1.24 \mu \mathrm{m}$ channels, Geophys. Res. Lett., 29, 1890, doi:10.1029/2002GL015475, 2002.
Glantz, P., Johansson, C., Kokhanovsky, A., and von HoyningenHuene, W.: Estimating $\mathrm{PM}_{2.5}$ over southern Sweden using spaceborne optical measurements, Atmos. Environ., 43, 5838-5846, 2009a.

Glantz, P., Nilsson, D. E., and von Hoyningen-Huene, W.: Estimating a relationship between aerosol optical thickness and surface wind speed over the ocean, Atmos. Res., 92, 58-68, $2009 \mathrm{~b}$.

Holben, B. N., Eck, T. F., Slutsker, I., Tanré, D., Buis, J. P., Setser, A., Vermote, E., Reagan, J. A., Kaufman, Y. J., Nakajima, T., Lavenu, F., Jankowiak, I., and Smirnov, A., AERONET - A federated instrument network and data archive for aerosol characterization, Remote Sens. Environ., 66, 1-16, 1998.

IPCC: Climate Change 2007: The Physical Science Basis, in: Contribution of Working Group I to the Fourth Assessment Report of the Intergovernmental Panel on Climate Change, edited by: Solomon, S., Qin, D., and Manning, M., Cambridge University Press, Cambridge, UK, 2007.

Kahn, R. A., Gaitley, B. J., Martonchik, J. V., Diner, D. J., Crean, K. A., and Holben, B.: Multiangle Imaging Spectroradiometer (MISR) global aerosol optical depth validation based on 2 years of coincident Aerosol Robotic Network (AERONET) observations, J. Geophys. Res., 110, D10S04, doi:10.1029/2004JD004706, 2005.

Kahn, R. A., Nelson, D. L., Garay, M. J., Levy, R. C., Bull, M. A., Diner, D. J., Martonchik, J. V., Paradise, S. R., Hansen, E. G., and Remer, L. A., MISR aerosol product attributes, and statistical comparisons with MODIS, IEEE T. Geosci. Remote, 47, 40954114, 2009.

Kahn, R. A., Garay, M. J., Nelson, D. L., Levy, R. C., Bull, M. A., Diner, D. J., Martonchik, J. V., Hansen, E. G., Remer, L., and Tanré, D.: Response to "Toward unified satellite climatology of aerosol properties", 3. MODIS versus MISR versus AERONET, J. Quant. Spec. Ra., 112, 901-909, 2011.

Kaufman, Y. J., Tanré, D., Gordon, H. R., Nakajima, T., Lenoble, J., Frouin, R., Grassl, H., Herman, B. M., King, M. D., and Teillet, P. M.: Passive remote sensing of tropospheric aerosol and atmospheric correction for the aerosol effect, J. Geophys. Res., 102, 16815-16830, 1997

Kokhanovsky, A. A.: Reflection and transmission of polarized light by optically thick weakly absorbing random media, J. Opt. Soc. Am., 18, 883-887, 2001.

Kokhanovsky, A. A., Deuzé, J. L., Diner, D. J., Dubovik, O., Ducos, F., Emde, C., Garay, M. J., Grainger, R. G., Heckel, A., Herman, M., Katsev, I. L., Keller, J., Levy, R., North, P. R. J., Prikhach, A. S., Rozanov, V. V., Sayer, A. M., Ota, Y., Tanré, D., Thomas, G. E., and Zege, E. P.: The inter-comparison of major satellite aerosol retrieval algorithms using simulated intensity and polarization characteristics of reflected light, Atmos. Meas. Tech., 3, 909-932, doi:10.5194/amt-3-909-2010, 2010.

Levy, R. C., Remer, L. A., Mattoo, S., Vermote, E. F., and Kaufman, T. J., Second-generation operational algorithm: Retrieval of aerosol properties over land from inversion of Moderate Resolution Imaging Spectroradiometer spectral reflectance, J. Geophys. Res., 112, D13211, doi:10.1029/2006JD007811, 2007.

Levy, R. C., Remer, L. A., Kleidman, R. G., Mattoo, S., Ichoku, C., Kahn, R., and Eck, T. F.: Global evaluation of the Collection 5 MODIS dark-target aerosol products over land, Atmos. Chem. Phys., 10, 10399-10420, doi:10.5194/acp-10-10399-2010, 2010. 
Li, R., Remer, L., Kaufman, Y., Mattoo, S., Gao, B., and Vermote, E.: Snow and ice mask for the MODIS aerosol products, IEEE Geosci. Remote S., 2, 306-310, 2005.

Liu, Y., Sarnat, J. A., Coull, B. A., Koutrakis, P., and Jacob, D. J.: Validation of MISR aerosol optical thickness measurements using Aerosol Robotic Net- work (AERONET) observations over the contiguous United States, J. Geophys. Res., 109, D06205, doi:10.1029/2003JD003981, 2004.

Martins, J., Tanre, D., Remer, L., Kaufman, Y., Mattoo, S., and Levy, R.: MODIS Cloud screening for remote sensing of aerosols over oceans using spatial variability, Geophys. Res. Lett., 29, 1619, doi:10.1029/2001GL013252, 2002.

Mishchenko, M. I., Liu, L., Geogdzhayev, I. V., Travis, L. D., Cairns, B., and Lacis, A. A.: Toward unified satellite climatology of aerosol properties, 3. MODIS versus MISR versus AERONET, J. Quant. Spectrosc. Ra., 111, 540-552, 2010.

Remer, L. A., Kleidman, R. G., Levy, R. C., Kaufman, Y. J., Tanré, D., Mattoo, S., Martins, J. V., Ichoku, C., Koren, I., Yu, H., and Holben, B. N.: Global aerosol climatology from the MODIS satellite sensors, J. Geophys. Res., 113, D14S07, doi:10.1029/2007JD009661, 2008.

Rohen, G. J., von Hoyningen-Huene, W., Kokhanovsky, A., Dinter, T., Vountas, M., and Burrows, J. P.: Retrieval of aerosol mass load $\left(\mathrm{PM}_{10}\right)$ from MERIS/Envisat top of atmosphere spectral reflectance measurements over Germany, Atmos. Meas. Tech., 4, 523-534, doi:10.5194/amt-4-523-2011, 2011.

Smirnov, A., Holben, B. N., Eck, T. F., Dubovik, O., and Slutsker, I.: Cloud screening and quality control algorithms for the AERONET database, Remote Sens. Environ., 73, 337-349, 2000.
Stohl, A., Berg, T., Burkhart, J. F., Fjǽraa, A. M., Forster, C., Herber, A., Hov, Ø., Lunder, C., McMillan, W. W., Oltmans, S., Shiobara, M., Simpson, D., Solberg, S., Stebel, K., Ström, J., Tørseth, K., Treffeisen, R., Virkkunen, K., and Yttri, K. E.: Arctic smoke - record high air pollution levels in the European Arctic due to agricultural fires in Eastern Europe in spring 2006, Atmos. Chem. Phys., 7, 511-534, doi:10.5194/acp-7-511-2007, 2007.

Treffeisen, R., Tunved, P., Ström, J., Herber, A., Bareiss, J., Helbig, A., Stone, R. S., Hoyningen-Huene, W., Krejci, R., Stohl, A., and Neuber, R.: Arctic smoke - aerosol characteristics during a record smoke event in the European Arctic and its radiative impact, Atmos. Chem. Phys., 7, 3035-3053, doi:10.5194/acp-73035-2007, 2007.

von Hoyningen-Huene, W., Freitag, M., and Burrows, J. B.: Retrieval of aerosol optical thickness over land surface from top-of-atmosphere radiance, J. Geophys. Res., 108, 4260, doi:10.1029/2001JD002018, 2003.

von Hoyningen-Huene, W., Kokhanovsky, A., Burrows, J. P., Bruniquel-Pinel, V., Regner, P., and Baret, F.: Simultaneous determination of aerosol- and surface characteristics from top-ofatmosphere reflectance using MERIS on board of ENVISAT, Adv. Space Res., 37, 2172-2177, 2006.

von Hoyningen-Huene, W., Yoon, J., Vountas, M., Istomina, L. G., Rohen, G., Dinter, T., Kokhanovsky, A. A., and Burrows, J. P.: Retrieval of spectral aerosol optical thickness over land using ocean color sensors MERIS and SeaWiFS, Atmos. Meas. Tech., 4, 151-171, doi:10.5194/amt-4-151-2011, 2011.

Winker, D. M., Vaughan, M. A., Omar, A., Hu, Y., Powell, K. A., Liu, Z., Hunt, W. H., and Young, S. A.: Overview of the CALIPSO Mission and CALIOP Data Processing Algorithms, J. Atmos. Ocean. Tech., 26, 2310-2323, 2009. 